JPH: Jurnal Pembaharuan Hukum

Volume 8, Number 3, December 2021

\title{
THE IMPLEMENTATION OF PROGRESSIVE LAW AGAINST THE DEFENDANT ABILITY TO ACHIEVE SUBSTANTIVE JUSTICE
}

\author{
Rr. Dijan Widijowati \\ Universitas Jayabaya, Jakarta, Indonesia \\ turizdiyan00@yahoo.com
}

\begin{abstract}
The enactment of the law in society aims to create justice, legal certainty, benefit and social empowerment for the community, to lead to the ideals of the court as a protector of society, the judge must always prioritize the 4 (four) legal objectives above in every decision he makes. This is in line with what the law is based on, namely the law for the welfare of the community. The poor are often victims of unfair law enforcement due to their ignorance of law enforcement and financial incompetence. The purpose of this study is to analyze the progressive law applied to poor defendants seeking substantive justice and to find out and analyze the state should be able to assist poor defendants in the judicial process in accordance with the rule of law principle. This research uses normative juridical method. Judges in deciding legal cases for the poor should have a progressive view, thus judges will conceptualize each article in the legislation not only as a statement about the existence of a causal (cause and effect) relationship that is straightforward according to logical law but also always contains moral substance originating from ethics and professionalism of judges.
\end{abstract}

Keywords: Defendant; Law; Poverty; Progressive.

\section{A. INTRODUCTION}

Law enforcement institutions in Indonesia consist of the police, prosecutors, advocates and judges. Of the four elements, the judge plays the most important role. This is because judges have the authority to decide cases and determine who is right and who is wrong. ${ }^{1} \mathrm{~A}$ judge is a state judicial official who is authorized by law to adjudicate a case before him. Therefore, judges in the settlement of cases in court have an important role considering their existence is included in the jurisdiction of the judiciary which is authorized to examine, hear, and decide cases. ${ }^{2}$

The relationship between law, judges and justice which is the embodiment of substantive justice in accordance with the values of Pancasila is very dependent on the legal thinking applied by judges in court. To find substantive justice, the judge's thinking must be based on progressive law. It's

1 Ahmad Rifai, Penemuan Hukum oleh Hakim dalam Perspektif Hukum Progresif, Sinar Grafika, Jakarta, 2010, page. 3.

2 Firman Floranta Adonara, Prinsip Kebebbasan Hakim dalam Memutus Perkara sebagai Amanat Konstitusi, Jurnal Konstitusi, Vol. 12 No. 2, 2015, page. 217. 
just that, looking at the reality that is currently happening, most judges' thoughts in the law enforcement process are not based on progressive legal thinking, but are still based on legalistic-positivistic views that the law is only a law and only pursues legal certainty times sacrificing the community's sense of justice.

Judges in the field of Criminal Law are tasked with determining precisely the criminal law that has been violated by the defendant. ${ }^{3}$ The defendant is someone who because of his actions or circumstances based on evidence at least is accused of committing a criminal act and then prosecuted ${ }^{4}$, examined and tried in court. ${ }^{5}$ The term progressive law was first introduced by Satjipto Rahardjo who was motivated by his concern with the low contribution of legal science in enlightening the Indonesian nation and in overcoming crises, including the crisis in the legal field itself. Progressive law means laws that are advanced or laws that change rapidly, make fundamental reversals in legal theory and practice and make various breakthroughs. ${ }^{6}$ Progressive law is a radical law by changing the legal system to make the law more useful.

The concept of progressive legal thought is one of the important thoughts in the development of law which was first put forward by Satjipto Rahardjo. Progressive law starts from the basic assumption that law is an institution that aims to deliver humans to a just and prosperous life and make humans happy. Progressive law in other words is a law that wants to liberate, both in the way of thinking and acting in law so that it is able to let the law flow to complete its task to serve humans and humanity. ${ }^{7}$

The method used by judges to apply progressive legal thinking in the context of realizing substantive justice is the method of legal discovery. Legal discovery is usually defined as the process of law formation by judges or other legal officers who are assigned the task of implementing the law on concrete legal events. Furthermore, Eikema Hommes also said that legal discovery is the application of legal regulations by judges or other legal apparatus assigned to the application of general legal rules to concrete legal events. ${ }^{8}$ There are 2 (two) schools of law discovery, namely progressive and conservative schools.

3 Wirjono Prodjodikoro, Asas-asas Hukum Pidana di Indonesia, Refika Aditama, Bandung, 2003, page. 26.

4 A Chuasanga, Ong Argo Victoria, Legal Principles Under Criminal Law in Indonesia and Thailand, Jurnal Daulat Hukum, Vol.2 No.1, 2019

5 Adnan Paslyadja, Hukum Pembuktian, Pusat Diklat Kejaksaan Republik Indonesia, Jakarta, 1997, page.69.

6 Satjipto Rahardjo, Hukum Progresif: Aksi Bukan Teks dalam Memahami Hukum dari Konstruksi sampai dengan Implementasi, Rajawali Pers, Jakarta, 2009, page. 6.

7 Sudjito, Hukum dalam Pelangi Kehidupan, Gadjah Mada University Press, Yogyakarta, 2012, page. 133.

8 Herowati Poesoko, Penemuan Hukum oleh hakim dalam Penyelesaian Perkara Perdata, Jurnal Hukum Acara Perdata (Adhaper), Vol. 1 No. 2, 2015, page. 228. 
Progressive schools argue that law and justice are only to prevent the decline of morals and other values. ${ }^{9}$

The judge in this case is different from the prosecutor who must side with the interests of the state and try to prove the defendant's guilt on the grounds of upholding law and justice. Judges are also different from advocates who side with the interests of the defendant as his client so that the lawyer in this case tries to find weaknesses and leniency in the prosecutor's evidence with reasons for upholding law and justice. ${ }^{10}$

The poor are often victims of unfair law enforcement. Given the fact that in essence it is also a structural force, there is no doubt that people who are in the upper strata position will always control a much more strategic position to mobilize their institutional power called law than the poor who are trapped in the lower strata position. ${ }^{11}$

The realization of a guarantee of a sense of justice for people seeking justice requires judges who have good legal analysis skills, integrity, morals and ethics. The judge in this case may not side with one of the parties in the court. The definition of a poor person or an underprivileged person in this case is a person who cannot fulfill his basic rights properly and independently who is facing legal problems. Based on the Instruction of the Minister of Justice of the Republic of Indonesia Number: M.03-UM.06.02 of 1999 concerning Guidelines for the Implementation of Legal Aid Programs for Underprivileged Groups of People through District Courts and State Administrative Courts, ${ }^{12}$ those who are underprivileged are people who have very small incomes so that their income is not sufficient to finance their cases in court, this condition of incapacity is determined by the Head of the District Court based on the statement of the Village Head.

The provision of legal aid to defendants who cannot afford further is also regulated in Article 27 of the Circular Letter of the Supreme Court (SEMA) Number 10 of 2010 concerning Guidelines for Providing Legal Aid, which states that:

"Those who are entitled to services from the Legal Aid Post are people who cannot afford the services of an advocate, especially women and children and persons with disabilities, in accordance with the applicable laws and regulations".

9 Sudikno Mertokusumo, Mengenal Hukum, Liberty, Yogyakarta, 1988, page. 147.

10 A. Muliadi, Peran Politik Hukum dalam Penegakkan Hukum yang Berkeadilan, Jurnal Hukum Adil, Vol.2 No.2, page. 160.

11 Soetandyo Wignjosoebroto, Hukum dan Masyarakat dalam Masyarakat, Perkembangan dan Masalah: Sebuah Pengantar ke Arah Kajian Sosiologi Hukum, Bayumedia Publishing, Malang, 2008, page. 186.

12 Nike Sepvinasari dan Zulfikar Judge, Pelaksanaan Pemberian Bantuan Hukum secara CumaCuma Kepada Terdakwa yang Tidak Mampu di Pengadilan Negeri Jakarta Barat, Lex Jurnalica, Vol. 12, No. 3, 2015, page. 243. 
Such legal aid includes exercising power of attorney, accompanying, representing, defending and/or taking other legal actions for the legal interest of the Legal Aid Recipient, the objectives of which include:

1. Guarantee and fulfill the rights of Legal Aid Recipients to get access to justice.

2. Realizing the constitutional rights of all citizens in accordance with the principle of equality in law.

3. Ensuring certainty that the implementation of legal aid is carried out evenly throughout the territory of the Indonesian state.

4. Realizing an effective, efficient, and accountable judiciary.

The debate about a just law is a debate that lasts all along the course of human history. Fair law enforcement is the dream of everyone who has reason. However, it is again seen that in Indonesia, the reality is that the poor are often powerless before the law. The judge's sentencing of Minah's grandmother and Asyani's grandmother really stirred conscience and hurt the Indonesian people's sense of justice. Especially when compared to various other cases involving well-off people. Justice is one of the main objectives of the law in addition to the benefits and legal certainty. ${ }^{13}$ According to Sudikno Mertokusumo, justice includes 2 (two) things, namely the nature of justice and the content or norms to act concretely in certain circumstances. The essence of justice is an assessment of a treatment or action by examining it through a norm which according to a subjective view exceeds other norms. ${ }^{14}$

Notohamidjodjo distinguishes justice into 2 (two) kinds, namely creative justice (justitia creativa) and protective justice (justita protectiva). Creative justice is justice that gives everyone the freedom to create everything according to their creative power. Protective justice is justice that provides shelter or protection to everyone in society. ${ }^{15}$

Based on this discussion, the purpose of this study is to find out and analyze how progressive law is applied to poor defendants who seek substantive justice and how the state should be able to assist poor defendants in the judicial process in accordance with the principles of the rule of law.

\section{B. RESEARCH METHODS}

The approach method used in this research is a normative juridical approach. The research method with a normative juridical approach is a process to find a rule of law, legal principles, and legal doctrine to answer the

13 Achmad Ali, Menguak Tabir Hukum-Suatu Kajian Filosofis dan Sosiologis, Gunung Agung, Jakarta, 2002, page. 72.

14 Sudikno Mertokusumo, Op.cit, page. 72.

15 Bayu Setiawan, Penerapan Hukum Progresif oleh Hakim untuk Mewujudkan Keadilan Substantif Transedensi, Jurnal Kosmik Hukum, Vol. 18, No. 1, January 2018, page. 44. 
legal problems faced. ${ }^{16}$ This research uses normative legal research because it will later be used to examine various laws and regulations. The focus of normative legal research is an inventory of positive law, legal principles and doctrines as well as legal findings in cases in concreto.

\section{RESULTS AND DISCUSSION}

\section{Progressive Law Applies To Poor Defendants Who Seek Substantive Justice}

The term progressive law was first introduced by Satjipto Rahardjo. In this case, he interprets progressive law as, first, the law is for humans and not the other way around. the law does not exist for itself, but for something broad, namely for human dignity, happiness, welfare and human glory. Second, law is not an absolute and final institution, because law is always in the process of continuing to be (law as a process, law is making). ${ }^{17}$

In this regard, in principle, one of the problems that are still rooted in our law enforcement is related to justice for the poor. In this case, the application of progressive law against poor defendants who seek substantive justice needs to be echoed, considering that most poor people do not understand or understand related to legal issues. This is what ultimately causes someone to break the law. As in the legal case, Minah's grandmother who did not know that her act of taking 3 (three) cocoa or chocolate pods was categorized as a crime of theft and was subject to Article 362 of the Criminal Code (KUHP). In this regard, Minah's grandmother, who is not only illiterate, $^{18}$

Ignorance of the law also causes a person to be fooled by individuals to take advantage, these individuals are usually ordinary people, the government or law enforcement officers. Asyani's grandmother's legal case illustrates this, where Asyani's grandmother who has kept 7 (seven) logs measuring 10-15 centimeters which is the result of her late husband's cutting 5 (five) years ago is charged with illegal logging. ${ }^{19}$ Perum Perhutani reported Asyani's grandmother to the police with the aim of providing a deterrent effect on Asyani's grandmother who was accused of stealing wood in the forest belonging to Perum Perhutani. The police officers who examined Asyani's grandmother did not give Asyani's grandmother an

16 Siti Rodhiah Dwi Istinah, Sri Kusriyah, dan Rakhmad Bowo Suharto, The Human Rights Protection In The Economic Affairs of Indonesia, Jurnal Pembaharuan Hukum, Vol. 8 No. 2, 2021, page. 278.

17 Liky Faizal, Problematika Hukum Progresif di Indonesia, Ijtimaiyah; Jurnal Pengembangan Masyarakat Islam, Vol. 9, No. 2, 2016, page. 4-5.

18 Widodo Dwi Putro, Mencari Kebenaran Materiil dalam Hard Case Pencurian Tiga Buah Kakao; Kajian Putusan No. 247/Pid.B/2009/PN.PWT, Jurnal Yudisial: Pergulatan Nalar \& Nurani, Vol. III, No. 3, 2010, page. 222.

19 Umar Sholahudin, Keadilan Hukum bagi si Miskin: Sebuah Elegi si Miskin di Hadapan Tirani Hukum, Journal of Urban Sociology, Vol.1 No.1 April 2018, page. 32. 
opportunity to be accompanied by legal counsel which was the right of Asyani's grandmother and then the judge in court decided that Asyani's grandmother was found guilty of illegal logging. The context of law enforcement against these vulnerable groups requires affirmative action/policy. Poor or vulnerable groups of people should be treated differently in different situations and conditions with positive reasons. This is necessary so that the differences experienced by the poor do not continue to occur. Based on the nature and character of poverty, ${ }^{20}$

If the poor lack or even lack legal awareness, the legal aid that will be provided will not function optimally. Therefore, the provision of legal aid for the poor should not be limited to assistance in the legal process if the poor have a lawsuit against the law, but more than that. The provision of legal aid for the poor must be able to make the poor understand the law and criticize existing legal products, namely by providing legal and civic education for the community. Progressive law is a concept about the way of law. There are many different ways of ruling and progressive law has its place. The progressive legal method is not just applying positive, legalistic law, implementing laws, reading or spelling laws and implementing them like a machine, but an action or effort (effort). This way of punishing is more energy draining, both thoughts and empathy and courage. ${ }^{21}$

Based on this, efforts to uphold the values of justice are more important than just carrying out various formal legislative procedures which are often associated with law enforcement. The term upholding justice is more appropriate than enforcing the law. This is because especially in the political field, the definition of law is often narrowed down to the procedures contained in a statutory regulation. In fact, the sense of justice will not be established if law enforcement officers only take action based on articles in a statutory regulation rigidly and do not explore substantive values of justice. According to Satjipto Rahardjo, progressive law enforcement is carrying out the law, not just black and white words from regulations (according to the letter), ${ }^{22}$ Law enforcement is not only intellectually intelligent, but also spiritually intelligent, so that law enforcement must be carried out with full determination, empathy, dedication, commitment to the suffering of the nation and accompanied by finding other ways than what is usually done. ${ }^{23}$

In line with that, judges are not just mouthpieces of the law, but must be able to convey decency, justice, public interest and order. Judges are obliged to choose decency, justice, public interest and public order if the

20 Ibid.

21 Satjipto Rahardjo, Op.cit, page. 3.

22 Mukhidin, Hukum Progresif sebagai Solusi Hukum yang Mensejahterakan Rakyat, Jurnal Pembaharuan Hukum, Vol. 1, No. 3, 2014, page 269.

23 H. Deni Nuryadi, Teori Hukum Progresif dan Penerapannya di Indonesia, Jurnal IImiah Hukum De'Jure: Kajian IImiah Hukum, Vol. 1, No. 2, 2016, page. 398. 
application of legal regulations would conflict with decency, justice, public interest or public order.

\section{State Assistance to Poor Defendants in the Judicial Process in accordance with the Rule of Law Principles}

The implementation of the provision of legal aid provided to recipients of legal aid is one of the state's efforts to realize the constitutional rights of citizens, especially people who are classified as poor. Efforts to provide legal aid to the poor are part of the implementation of a state of law that recognizes and protects and guarantees the rights of citizens (equality before law). ${ }^{24}$ Legal aid is a legal service that recognizes and protects and guarantees the rights of citizens to the need for access to justice and equality before the law. In line with that, Soerjono Soekamto quoting Adnan Buyung Nasution stated that legal aid in this sense must also provide services that educate and raise awareness and rights as legal subjects as well as carry out legal reforms and improvements. ${ }^{25}$

The provision of legal aid by the Legal Aid Institute has a very large role, namely to assist clients so that legal aid recipients will not be treated arbitrarily by the authorities and to defend material-related matters to get a sense of justice. ${ }^{26}$ This is important to do considering that in an effort to settle through criminal justice as regulated in the Criminal Code and its implementing rules, it divides the criminal justice process into several levels, namely: $:^{27}$
a. Level of investigation by investigator
b. Level of investigation and additional investigation by investigators
c. The level of prosecution by the public prosecutor
d. Examination at court level by judge

In this regard, to obtain legal aid, there are conditions that must be met and are regulated in Article 14 of Act No. 16 of 2011 concerning Legal Aid. The conditions are as follows:
a. Submit a written application that contains at least the identity of the applicant and a brief description of the subject matter for which legal assistance is being requested.
b. Submit documents related to the case.

24 Ajie Ramdan, Bantuan Hukum sebagai Kewajiban Negara untuk Memenuhi Hak Konstitusional Fakir Miskin, Jurnal Konstitusi, Vol. 11, No. 2, 2014, page. 235.

25 Enny Agustina, Susanti Eryanti, Virna Dewi, dan Rahmiati Ranti Pawari, Lembaga Bantuan Hukum dalam Perspektif Hak Asasi Manusia, Solusi, Vol. 19, No. 2, 2021, page. 217.

26 Angga dan Ridwan Arifin, Penerapan Bantuan Hukum bagi Masyarakat Kurang Mampu di Indonesia, Diversi Jurnal Hukum, Vol. 4, No. 2, 2018, page. 227.

27 Andri Winjaya Laksana dan Sisca Dyah Octaviani, Implementationof Law Enforcements Againts Crime With Small Motive Patterned Restorative Justice, Iinternational Journal of Law Reconstruction, Vol. 3, No. 1, 2019, page. 24. 
c. Attach a certificate of poverty from the village head or an official at the same level as the legal aid applicant's place of residence.

d. In the event that the applicant for legal aid is unable to prepare a written application, the application can be submitted orally.

Based on this, efforts to provide legal aid to the poor are very important, considering that this is an important part of law enforcement efforts to seek justice. This is because the law enforcement process is an important part of the rule of law, because without law enforcement, order will never be created, so rules are just words that have no meaning. However, if they have to fulfill the requirements based on the provisions in Article 14 of Act No. 16 of 2011 concerning Legal Aid, the poor will find it difficult to obtain legal aid. ${ }^{28}$ Although referring to point 4 in Article 14 of Act No. 16 of 2011 concerning Legal Aid, it is stated that in the event that the applicant for legal aid is unable to prepare a written application, the application can be submitted orally.

In general, the poor are people who are blind to the law, do not have internal gaining power law and do not have the courage to express their opinions and have difficulty in conveying their desire to obtain legal assistance.

The mechanism for providing legal assistance in criminal cases at the examination stage in court is that when the trial begins, the judge will ask the defendant who is categorized as a poor community, whether the defendant wants to be accompanied by legal counsel or not. If the defendant accepts legal assistance, the trial will be adjourned to appoint legal counsel. Defendants belonging to the poor will generally receive legal assistance from Legal Aid Organizations (OBH), but Legal Aid Organizations $(\mathrm{OBH})$ often encounter obstacles in providing legal assistance to the poor, including:

a. Legal substance factor. Act No. 16 of 2011 concerning Legal Aid still has weaknesses, because in the law, legal aid recipients are only poor people or groups of poor people.

b. Law enforcement factors from an external perspective show that many advocates have never provided legal assistance on the grounds that there was no summons or no police or court investigators who contacted the advocate concerned.

The mechanism for providing legal assistance in criminal cases at the examination stage in court is that when the trial begins, the judge will ask the defendant who is categorized as a poor community, whether the defendant wants to be accompanied by legal counsel or not. If the

28 Bambang Tri Bawono, The Strategy for Handling Corruption's Criminal Action Relationship to Saving of State Financial Losses, Jurnal Pembaharuan Hukum, Vol. 7 No. 3, 2020, page. 225. 
defendant accepts legal assistance, the trial will be adjourned to appoint legal counsel. Defendants belonging to the poor will generally receive legal assistance from Legal Aid Organizations (OBH), but Legal Aid Organizations $(\mathrm{OBH})$ often encounter obstacles in providing legal assistance to the poor, including:

a. Legal substance factor. Act No. 16 of 2011 concerning Legal Aid still has weaknesses, because in the law, legal aid recipients are only poor people or groups of poor people.

b. Law enforcement factors from an external perspective show that many advocates have never provided legal assistance on the grounds that there was no summons or no police or court investigators who contacted the advocate concerned.

The justice system in Indonesia has adopted mediation by issuing Supreme Court Regulation No. 1 of 2008 concerning Mediation Procedures in Courts. Based on the provisions stipulated in Article 4 of the Regulation of the Supreme Court Number 1 of 2008 concerning Mediation Procedures in Courts, except for cases that are settled through commercial court procedures, industrial relations courts, objections to decisions of the Consumer Dispute Settlement Agency and objections to decisions of the Business Competition Commission, all civil disputes which is submitted to the Court of First Instance must first be resolved through reconciliation with the assistance of a mediator. Based on Supreme Court Regulation Number 1 of 2008 concerning Mediation Procedures in Courts, criminal cases are not included in the types of cases that can be mediated.

The sentences given to Minah's grandmother and Asyani's grandmother illustrate a legal process that is dead from the purpose of the law itself. The law in this case only follows formal rules without taking into account substance and conscience. The reality. The law should be sensitive to the sense of injustice that is often experienced by the poor.

The practice of legal injustice against the poor in Indonesia is still common. Law enforcement officials prioritize aspects of legal certainty, formal legality, rather than legal justice which is more substantial for the community. Many facts in the field show that when the poor are dealing with the law, the law that is highlighted is the law that only seeks formal truth and not substantial law. Substantial law is not a law that operates on articles but a law that operates and moves in the dynamics of society.

\section{CONCLUSION}

Application of Progressive Law by Judges to Poor Defendants Seeking Substantive Justice based on Rule of Law Principles, Judges in deciding legal cases for the poor should have a progressive view, thus judges will conceptualize each article in the legislation not only as a statement about the existence of a causal (cause and effect) relationship that is straightforward 
according to logical law but also always contains moral substance that comes from ethics and professionalism of judges. The court in this case is not only a punishment institution for the poor, but the court must be wise in making decisions. Substantive justice is justice that not only punishes someone but also improves someone's behavior. Progressive judges will prioritize restorative justice. Sentencing of crimes through restorative justice for the poor is the duty and responsibility of law enforcement officers to sharpen legal analysis and increase the sensitivity of the conscience of humanity. Regulation of Legal Aid for the Poor in the Judicial Process, if a criminal law case in which the perpetrator is a poor community, the judge should use his authority to become a mediator in penal mediation. This is because the settlement procedure through penal mediation is not formalistic, not based on blaming one party and oriented to future relationships. Formal penal mediation in court has advantages, namely the agreement reached has the same executorial power as a judge's decision and is final. The agreement produced in penal mediation can also vary, for example: 1) Payment of compensation in cash; 2) Payment of compensation in installments; 3) Payment of compensation paid by other parties; 4) Payment of compensation in the amount of money replaced with labor; and 5) Cooperation between the perpetrator and the victim. The application of penal mediation may be carried out in all criminal cases, especially in criminal cases where the perpetrators of criminal acts are poor people. However, one thing that must be considered is that the application of penal mediation in criminal cases is limited to crimes that are not considered serious or serious offenses, criminal acts whose punishment is less than 5 (five) years, the crime committed does not harm the state, the crime does not cause death, health and environmental problems.

\section{Books :}

\section{BIBLIOGRAPHY}

Adnan Paslyadja, 1997, Hukum Pembuktian, Jakarta: Pusat Diklat Kejaksaan Republik Indonesia

Achmad Ali, 2002, Menguak Tabir Hukum-Suatu Kajian Filosofis dan Sosiologis, Jakarta: Gunung Agung

Ahmad Rifai, 2010, Penemuan Hukum oleh Hakim dalam Perspektif Hukum Progresif, Jakarta: Sinar Grafika

Satjipto Rahardjo, 2009, Hukum Progresif: Aksi Bukan Teks dalam Memahami Hukum dari Konstruksi sampai dengan Implementasi, Jakarta: Rajawali Pers

------, 2006, Membedah Hukum Progresif, Kompas, Jakarta; 
Soetandyo Wignjosoebroto, 2008, Hukum dan Masyarakat dalam Masyarakat, Perkembangan dan Masalah: Sebuah Pengantar ke Arah Kajian Sosiologi Hukum, Bayumedia Publishing, Malang;

Sudikno Mertokusumo,1988, Mengenal Hukum, Liberty, Yogyakarta;

Sudjito, 2012, Hukum dalam Pelangi Kehidupan, Gadjah Mada University Press, Yogyakarta;

Wirjono Prodjodikoro, 2003, Asas-asas Hukum Pidana di Indonesia, Refika Aditama, Bandung;

\section{Journals :}

A. Muliadi, Peran Politik Hukum dalam Penegakkan Hukum yang Berkeadilan, Jurnal Hukum Adil, Vol. 2 No.2;

Ajie Ramdan, Bantuan Hukum sebagai Kewajiban Negara untuk Memenuhi Hak Konstitusional Fakir Miskin, Jurnal Konstitusi, Vol. 11 No. 2, 2014;

A Chuasanga, Ong Argo Victoria. (2019). Legal Principles Under Criminal Law in Indonesia and Thailand, Jurnal Daulat Hukum, Vol 2 No 1 2019;

Andri Winjaya Laksana dan Sisca Dyah Octaviani, Implementationof Law Enforcements Againts Crime With Small Motive Patterned Restorative Justice, Iinternational Journal of Law Reconstruction, Vol. 3 No. 1, 2019;

Angga dan Ridwan Arifin, Penerapan Bantuan Hukum bagi Masyarakat Kurang Mampu di Indonesia, Diversi Jurnal Hukum, Vol. 4 No. 2, 2018;

Bambang Tri Bawono, The Strategy for Handling Corruption's Criminal Action Relationship to Saving of State Financial Losses, Jurnal Pembaharuan Hukum, Vol. 7 No. 3, 2020;

Bayu Setiawan, Penerapan Hukum Progresif oleh Hakim untuk Mewujudkan Keadilan Substantif Transedensi, Jurnal Kosmik Hukum Vol. 18 No. 1, January 2018;

Enny Agustina, Susanti Eryanti, Virna Dewi, dan Rahmiati Ranti Pawari, Lembaga Bantuan Hukum dalam Perspektif Hak Asasi Manusia, Solusi, Vol. 19 No. 2, 2021;

Firman Floranta Adonara, Prinsip Kebebbasan Hakim dalam Memutus Perkara sebagai Amanat Konstitusi, Jurnal Konstitusi, Vol. 12 No. 2, 2015;

H. Deni Nuryadi, Teori Hukum Progresif dan Penerapannya di Indonesia, Jurnal Ilmiah Hukum De'Jure: Kajian IImiah Hukum, Vol. 1 No. 2, 2016;

Herowati Poesoko, Penemuan Hukum oleh hakim dalam Penyelesaian Perkara Perdata, Jurnal Hukum Acara Perdata (Adhaper), Vol. 1 No. 2, 2015; 
Liky Faizal, Problematika Hukum Progresif di Indonesia, Ijtimaiyah; Jurnal Pengembangan Masyarakat Islam, Vol. 9 No. 2, 2016;

Mukhidin, Hukum Progresif sebagai Solusi Hukum yang Mensejahterakan Rakyat, Jurnal Pembaharuan Hukum, Vol. 1 No. 3, 2014;

Nike Sepvinasari dan Zulfikar Judge, Pelaksanaan Pemberian Bantuan Hukum secara Cuma-Cuma Kepada Terdakwa yang Tidak Mampu di Pengadilan Negeri Jakarta Barat, Lex Jurnalica, Vol. 12 No. 3, 2015;

Siti Rodhiah Dwi Istinah, Sri Kusriyah, dan Rakhmad Bowo Suharto, The Human Rights Protection In The Economic Affairs of Indonesia, Jurnal Pembaharuan Hukum, Vol. 8 No. 2, 2021;

Umar Sholahudin, Keadilan Hukum bagi si Miskin: Sebuah Elegi si Miskin di Hadapan Tirani Hukum, Journal of Urban Sociology Volume 1 Nomor 1 April 2018;

------, Hukum dan Keadilan Masyarakat (Analisis Sosiologi Hukum terhadap Kasus Hukum Masyarakat Miskin Asyani di Kabupaten Situbondo), Dinensi, Vol. 9 No. 1 2016;

Widodo Dwi Putro, Mencari Kebenaran Materiil dalam Hard Case Pencurian Tiga Buah Kakao; Kajian Putusan No. 247/Pid.B/2009/PN.PWT, Jurnal Yudisial: Pergulatan Nalar \& Nurani, Vol. III No. 3 2010;

\section{Regulation :}

Act No. 16 of 2011 concerning Legal Aid;

Circular Letter of the Supreme Court (SEMA) Number 10 of 2010 concerning Guidelines for Providing Legal Aid;

Criminal Code;

Instruction of the Minister of Justice of the Republic of Indonesia Number: M.03UM.06.02 of 1999 concerning Instruction Implementation of the Legal Aid Program for Underprivileged Groups of People through District Courts and State Administrative Courts;

Supreme Court Regulation Number 1 of 2008 concerning Mediation Procedures in Courts. 